\title{
Indo-Pak Trade Relations under WTO Regime - A Study of Agriculture Sector
}

\author{
Mr. Sailen Das \\ Assistant Professor, Dept. of Political science, Murlidhar Girls College, Calcutta University, \\ Kolkata, India
}

\begin{abstract}
India and Pakistan, the two largest countries of South Asia, are struggling to improve their economies in order to meet the challenges of the highly competitive free market environment under the World Trade Organization (WTO).Socio-economic growth and political stability in Pakistan and India over the last few years show positive indicators that their economies are ready to go global under the WTO regime. This paper looks at the possibility of trade between India and Pakistan in the Agriculture Sector. Analysis of relative competitiveness in agricultural products indicates that Pakistan has considerable potential to export to India. And both countries have a comparative advantage in the export of some commodities to each other. It is observed that despite implementation of SAFTA, existence of tariff and non-tariff barriers continue to restrict agricultural trade between the two countries.
\end{abstract}

Keywords: India and Pakistan, WTO, Trade relations, Export, Import, SAFTA MFN, Agriculture.

\section{BACKGROUND AND CONTEXT}

Trade among neighboring nations has remained an important economic activity and has played a significant role in the economic development of trading partners. Basically, International trade assumes a great significance in economic development of both developed and developing countries. The literature on trade suggests that proximity is one of the major determinants of trade. Geographic proximity is also used as an important explanation for regional trade groupings or blocs. Often, regional economic relations are marred by historical hostility between neighbours, because of which neighbouring countries trade less with each other than with more distant countries. Trade between India and Pakistan is a classic case in this regard. Because of the historical hostility between the two countries, not much progress has been achieved in increasing regional trade in South Asia despite efforts to promote preferential trade. India-Pakistan relations are drawing considerable attention from the world at large, with the two countries now at a point where significant economic gains could serve as a powerful means for conflict resolution. (Chand 2006, p 2).

In the last three decades, particularly during 1990s and 2000s, most of the countries liberalized their trade as a part of economic reforms adopted by them and facilitated by the World Trade Organization (WTO) policies ${ }^{1}$. One of the most significant developments in the area of international trade is the emergence of regional groupings especially bilateral trade relations in the every part of World trading system.

\section{OBJECTIVE OF STUDY}

Basically, I do not want to explore Indo-Pak trade relations with statistics data or another way to say export, import or statically data analysis are not objective to this paper, the broad objective of my study is aimed at analyzing the terms and condition India and Pakistan trade relations under the world trading system and how they keep to normalize their trade relations after their lengthy political dispute. The current paper looks at the possibility of trade between India and Pakistan in the Agriculture sector under the WTO provision.

\section{Methodology and Data Analyze}

The study namely bilateral trade between India and Pakistan is conducted by using the secondary data. Data related to the problem is quite scattered and were extracted from different sources. : The 
study was based on the secondary data collected from various books, Journal and statistical sources. Some of the sources of these secondary data include: Ministry of Commerce, APEDA, National Sample Survey Organization (NSSO), Central Statistical Organization (CSO), and Centre for Monitoring Indian Economy (CMIE), and Directorate General of Commercial Intelligence and Statistics (DGCIS), and Indian institute of Foreign Trade, NEW Delhi (IIFT) etc. The paper uses time series data on agricultural exports to Pakistan and agricultural imports from Pakistan, which is taken from Export-Import Databank, Ministry of Commerce, and Government of India. The data on Pakistan's exports and imports to the World is taken from International Trade Centre website. Information on tariff and non-tariff barriers was taken from WTO, the respective Government websites and the MacMap website. Information related to SAFTA was obtained from the SAARC Website. Besides, various websites like faostat, indiastat, agricoop, etc. referrers for the study.

The study uses time series data on trade for 17 years from 1996-97 to 2012-13. The choice of the year 1996-97 was based on the consideration that this was the first year after the constitution of the WTO, which marked a new beginning in agricultural trade liberalization in many developing countries. A major development related to trade in South Asia took place with the formulation of South Asia Free Trade Agreement (SAFTA) which came into effect in 2006. The study compares trade trends by dividing the relevant time period in two phases i.e. before the formulation of SAFTA and after the formulation of SAFTA to assess its influence on the trade flows between the two countries. Thus, 2006-7 was taken as the benchmark year for analyzing trade trends between India and Pakistan. Trade trends during 2006-07 to 2012-13. This comparison was used to reveal the effect of the regional trade agreement on bilateral agricultural trade.

\section{Brief History Of INDia-PAKistan BILATERAL Trade Relation}

In order to fully understand what has happened over the last year, it may be useful to look at the historical perspective, right from the time that the two countries became independent. Mr. M.A. Jinnah, the founding father of Pakistan, had a very positive vision for India-Pakistan relations. In 1948-49, Pakistan's exports to India accounted for 56 percent of its total exports, while 32 percent of Pakistan's imports came from India. The two countries were trading normally during this turbulent period. India was Pakistan's largest trading partner, and this continued to be the case until 1955-56. Between 1948 and 1965, India and Pakistan used a number of land routes for bilateral trade. These included eight customs stations in Punjab province and three custom check posts in Sindh. Pakistan and India, invoking Article 24/paragraph 3(a) of $\mathrm{GATT}^{2}$, even signed a bilateral agreement on December 22, 1957, to facilitate border trade. From 1947 to 1965, Pakistan and India entered into 14 bilateral agreements related to trade facilitation. Both Pakistan and India had bank branches in each other's country. In 1965, there were nine branches of six Indian banks operating in Pakistan. But, the unresolved Kashmir dispute came into play. In 1965, war broke out between the two countries. This time, trade and economic relations became causalities of war. After the 1971 war, the Simla Agreement was signed between Pakistan and India in 1972. Under this agreement, trade resumed on a limited scale in 1974. Both countries worked on positive lists, which expanded incrementally over the years. This continued until 1995, when, upon signing the World Trade Organization agreement, India's exports to Pakistan jumped significantly in 1996-97 and again in 2000-01. The steady rise in India's exports is visible after 2000. As Pakistan has been shifting products to 'positive list' gradually, India's exports responded accordingly. However, India's import from Pakistan remained at a very low level throughout the last decade. During the third round of Composite Dialogue process discussions in March 2006, both countries agreed to discuss the new shipping protocol, the deregulations of air services, the joint registration of basmati rice, an increase in the size of Pakistan's positive list, proposals for information-technology-related medical services and export insurance by India, and work on a memorandum of understanding for cooperation in capital markets by Pakistan. During the 6th Round of Commerce Secretary Level Talks in November 2011 at New Delhi, both countries agreed to develop mechanisms to address issues of Non-Tariff Barriers. In November 2011 Pakistan decided to grant the Most Favoured Nation (MFN) ${ }^{3}$ status to India to boost bilateral trade. Since 201112, total trade between these two countries crossed the US $\$ 2$ billion mark and in 2012-13, it touched US $\$ 2.4$ billion. Pakistan's exports increased by 28 per cent and for India the increase is of 19 per cent in 2012-13. (Mahmood 2013, p 21)

The government of the Pakistan People's Party (PPP) decided to postpone implementation of India's MFN status until after the 2013 elections, leaving the new government to make the final decision. The 
Pakistan Muslim League-Nawaz (PML-N) government similarly postponed a decision in March 2014 to move ahead with MFN. Because of controversy surrounding the term, MFN is now referred to as 'Non-Discriminatory Market Access' (NDMA) ${ }^{4}$ in Pakistan.

In late 2015 there was a warming of relations, giving rise to some optimism that trade talks would come back on track. Unfortunately, the terrorist attack on India's Pathankot Air Force base on 2 January 2016 and Indian Army base at Uri in Baramullah district in north Kashmir on $18^{\text {th }}$ September 2016 recreated an atmosphere of suspicion, and Indian accusations of Pakistani complicity could potentially derail talks. ${ }^{5}$ Still, there is hope that the matter will be settled as the Pakistani government has agreed to investigate whether the attacks were directed by groups based in Pakistan.

\section{Indo-Pak Trade ANd Trading Agreement}

Trade between India and Pakistan, due to political and strategic issues, has been fraught with hindrances. The establishment of SAARC (South Asian Association for Regional Co-operation) in 1985 can be remarked as the initiation of improving relations in the South Asian bloc, particularly between India and Pakistan. The launching of the South Asian Preferential trade Agreement (SAPTA) in 1995 was the first major political breakthrough for SAARC since it was India's first regional agreement on economic co-operation (Sawhney and Kumar, 2007, p56). Later, the signing of the SAFTA (South Asian Free Trade Area) Agreement in January 2004 was an attempt by SAARC countries to further integrate through trade and investment. Nepal, Bhutan, Maldives and Bangladesh comprised the least developed countries (LDCs) and Pakistan, India and Sri Lanka the non-LDCs (NLDCs). The trade liberalization programme of SAFTA has described the schedules of tariff reductions for LDCs and NLDCs. Along with this, the contracting states can maintain sensitive lists for which the tariff reduction schedules will not hold. Sensitive lists are lists of products of special interest to individual member countries that are exempted from low SAFTA tariffs. The use of sensitive lists allows countries to protect growing domestic industries or important sources of customs revenue. However, overuse of sensitive lists can make goods more expensive for consumers and reduce trade between countries. (Khan, 2009, p3) The LDCs and NLDCs have affirmed their existing rights and obligations with respect to each other under the Marrakesh Agreement establishing World Trade Organization (WTO). As members of the World Trade Organization (WTO), they are supposed to accord "most favoured nation" (MFN) status to each other. The MFN principle is a principle of non-discrimination embodied in the General Agreement on Trade and Tariffs (GATT), which means countries, cannot discriminate between their trading partners. The MFN principle ensures that each country treats the 159 fellow-members of WTO equally. But there are some exceptions for preferential treatment of developing countries, regional free trade areas and customs unions (World Trade Organization). India accorded the MFN status to Pakistan in 1996 and Pakistan has assured it will grant India MFN status soon. However, because Pakistan has not granted MFN status to India, it maintains a negative list for India. Items in Pakistan's negative list are those which are not allowed to be imported from India. Until 2011, Pakistan maintained a positive list for India specifying permitted items to be imported. It was when a joint statement was issued laying down full phasing-in of MFN in November 2011 that Pakistan shifted to a small negative list. Accordingly, India and Pakistan maintain a sensitive list for its SAFTA members and Pakistan, in addition, maintains a negative list for India. ${ }^{6}$

\section{Indo-Pak Trade in Agriculture Sector}

Trade in agriculture is arguably one of the most contentious and debated issues in global trade that is contextualized more often in the trade relations between the industrialized economies of the west and the developing world. However, seldom one hears about agriculture being a stumbling block to increased bilateral trade between developing countries. When it comes to the topic of trade between India and Pakistan, the general perception is that politics trumps economics-any effort to normalize trade and economic relations between the two countries is susceptible to an unpredictable and fragile political relationship. The Mumbai attacks, for example, undid whatever little was achieved to improve economic linkages in the years prior to it. More recently, the decision by the Pakistan government to grant Most Favored Nation status (MFN) to India by December 2012 has been delayed because of clashes at the border. However, this time political tensions were not the only reason-the agricultural lobby in Pakistan also played a significant role in delaying the decision to grant MFN to India. Various farmer associations across the country led demonstrations in Islamabad claiming that subsidized and cheap agricultural products from India would flood markets in Pakistan at the cost of 
farmers and the rural population. Pakistan's Senate took notice of their concerns, which subsequently led to the postponement in the implementation of the MFN status ${ }^{7}$.

However, SAFTA's effect on India-Pakistan trade is much sharper on trade of agricultural goods as compared to its effect on total trade (Figure 1). India's export of agricultural products remained small till the year 2004-05 and followed a U-shaped trend during 1996-97 to 2004-05. Exports declined from \$108 million to \$26 million between 1996-97 and 1999- 2000 and then rose to \$101 million in year 2003-04. In this period, Pakistan's total exports to India hovered around \$40 million, except in the year 1998-99, when its exports reached \$207 million - a record, which remained till the year 2012-13. Moreover, 1998-99 was the only year when Pakistan's exports to India exceeded its imports from India by a big margin. India' agricultural exports to Pakistan started picking up in the year 200506 and have increased substantially ever since. Exports increased three-and-a-half times to $\$ 722$ million in the year 2006-07. However, there was a break in this trend for three years, after which, exports of agricultural products from India to Pakistan increased again and crossed the $\$ 1$ billion mark. Thus, India's exports to Pakistan have been characterized by a cyclical pattern with an upward trend. Exports have increased too much higher levels since the implementation of SAFTA. India's annual imports of agricultural products from Pakistan, (alternatively, Pakistan's annual agricultural exports to India) have ranged between $\$ 100$ to $\$ 200$ million since the year 2005-06, the period beginning with a decline in exports followed by an increase. The sharp rise in India's exports to Pakistan resulted in exports exceeding imports by more than $\$ 500$ million in year 2006-07. The gap declined to less than half in subsequent years and again rose to another peak level of \$969 million in 2010-11. The net trade pattern has been determinate by the pattern of India' agriculture Exports to Pakistan because Pakistan's exports to India played a limited role in influencing it.

Agricultural trade trends between the two countries reveal a clear but one-time increase in year 200607, the year in which the SAFTA agreement was implemented. After 2006-07, agricultural exports from India to Pakistan remained higher than those from Pakistan to India in all years but show a lot of variability. Agricultural imports from Pakistan, though small, did not fluctuate as much as exports to Pakistan. It appears that a large part of India's export to Pakistan catered to stabilization of domestic supply in Pakistan. Such trade is usually not based on strong comparative advantage but on climatic factors causing production fluctuations in the destination country.

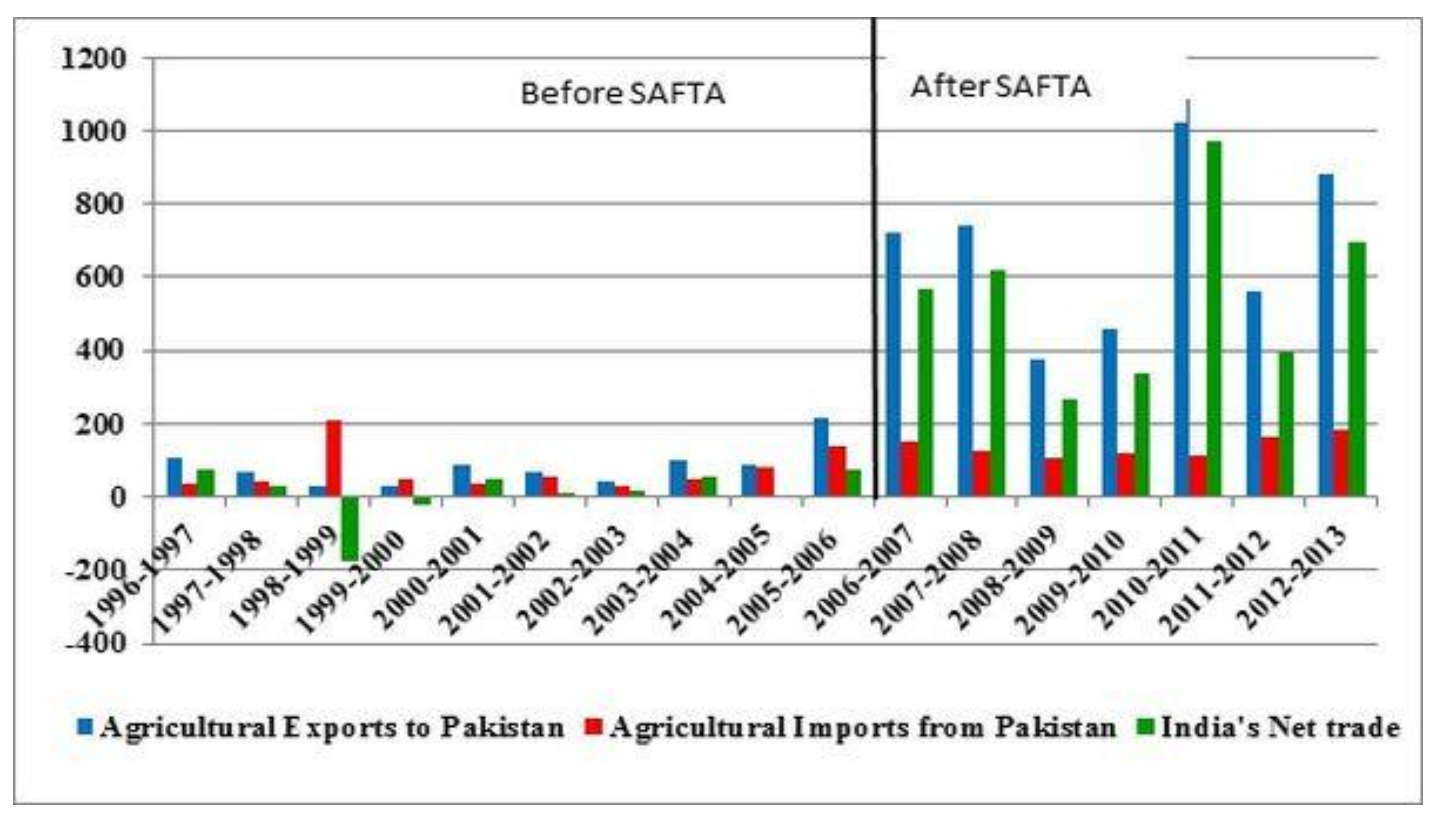

\section{Figure1}

\section{Source: EXIM databank, Ministry of Commerce, Government of India}

However, the importance of agriculture to the economies of both India and Pakistan cannot be overstated. The sector contributes a significant amount to the GDP and employment in both countries. Agriculture contributes to 21 per cent of GDP and constitutes 45 per cent of labor force Pakistan (Economic Survey of Pakistan 2012-13). In India it contributes 14 per cent to GDP and constitutes 58 per cent of labor force (Economic Survey of India 2012-13). In terms of size, India's agricultural production is more than five times that of Pakistan, yet Pakistan's per capita production across major 
crops is substantially higher than in India the geographical and climatic diversity across the two countries is a major factor behind differences in the variety and pattern of agriculture produce, creating considerable opportunities for trade. But perhaps the most important difference between the agriculture sectors of the two countries is their contrasting policy regimes. Post independence India, driven primarily by the objective of achieving food security, adopted and maintained an interventionist regime in agriculture. India continues to subsidize agricultural inputs, provides price support for 24 crops, and maintains a high average applied tariff rate on agricultural products. By contrast, Pakistan over the years has liberalized its agricultural sector with minimal state intervention. Market liberalization reforms have meant a gradual phasing out of subsidies and price supports, and a reduction in agricultural tariff rates. The only crop procured by the government at a fixed preannounced price is wheat; the rest are freely traded at market prices. From the standpoint of the agricultural sector in Pakistan, this difference in policy regime creates an uneven playing fieldsubsidies reduce costs of cultivation, distort prices, and affect the direction and volume of trade. The other contentious issue is that of market access. High average tariffs on agriculture goods and NonTariff Barriers (NTBs)on the Indian side such as health and quality standards (SPS and quarantine standards) are cited as major reasons for the relatively low Pakistani agricultural exports to India, despite India giving MFN to Pakistan in 1996. The non-issuance of visa for Indian Punjab is also highlighted as a major obstacle to trade in agricultural goods. Despite the fact that Pakistan has not extended MFN and maintains a negative list with India; both the overall and agricultural trade balance is still heavily tilted in India's favour. The major agriculture imports from India have been cotton, refined sugar and more recently, fresh vegetables. On the other hand, Pakistan's main agricultural export to India over the past two years has been dried dates (US\$ 47.2 million in 2011). Exports of onions, shallots, shrimps and apricots have recently picked up, but are still very small in terms of volume and value. Interestingly, trade in major crops (wheat and rice) between the two countries is non-existent, perhaps because of the relatively high applied tariffs. ${ }^{8}$

Analysis of relative competitiveness in agricultural products indicates that Pakistan has considerable potential to export to India. Various studies that have carried out Revealed Comparative Advantage (RCA) analysis show that Pakistan is competitive in citrus fruit, mangoes, apricots, peaches, olives, fish and fish products. These products have the potential to attract significant demand in Indian markets. Furthermore, India with its large population (a middle class of more than 300 million people) offers a lot of opportunities for export of value-added agricultural processed fresh and preserved food, dairy products, juices and vegetable food supplements. Niche export market opportunities also exist for vegetarian, halal, kosher and organic products $^{9}$

\section{FIND OUT}

Despite strong neighborhood and proximity advantage, India and Pakistan did not trade much until the late 1990s. Bilateral trade started expanding in the new century and it picked up momentum after SAFTA came into effect in 2006. In case of the agricultural sector, trade picked up after 2005-06. Since then, agricultural exports from India to Pakistan have grown at a faster rate than export of nonagricultural products. However, agricultural exports from Pakistan to India increased at a slow rate, seemingly due to supply side constraints in Pakistan's agricultural sector. Average trade showed a big jump after SAFTA came into effect, but it proved to be a one-time gain, as the trend remained sluggish after the increase in 2006-07. On the whole, India's agricultural exports to Pakistan show a much better performance than agricultural exports from Pakistan to India.

Trade in most commodities show very large year-on -year variation and most of the agriculture trade was taking place for stabilizing the fluctuations in domestic production. The trade pattern of the past 15 years indicates that the Indo-Pak agriculture trade can be classified in three categories namely (a) trade for domestic stabilization; (b) trade based on comparative advantage of more or less permanent nature, and (c) trade in specialized products. Some of India's major exports, like sugar, onion and even cotton, are meant largely for regulating the fluctuating domestic supply (due to production shocks) in Pakistan. Experience shows that there is considerable delay in arranging import on both sides to address domestic shortages. Suitable mechanisms need to be developed for liberalized trade in such commodities to address price shocks that hurt consumers and also adversely affect the economy. Bilateral trade is a cost effective and efficient instrument to address price and market volatility in the two countries. 
Both countries have comparative advantage in the export of some commodities to each other. These include tomato, cane sugar, onion, fresh vegetables, cotton (carded and combed), ground nut, coarse cereals as feed and dairy products for exports from India to Pakistan. Similarly, Pakistan has comparative advantage in exporting dates, leather, hides and skins and woven fabrics to India. There is considerable scope for promoting export of specialized items as trade is stable and growing in this case.

Despite implementation of SAFTA, some strong tariff and non-tariff barriers continue to restrict agricultural trade between the two countries. Such as Trade facilitation, further lowering of tariffs, Pruning the negative list, Removal of non-tariff trade barriers. Another important factor that I have found out is that differences in the level of agricultural subsidies between India and Pakistan are an important reason for not liberalizing India's agricultural export to Pakistan. As there is a huge difference in the size of the sector in the two countries, comparisons of subsidies make better sense in terms of the ratio or share. Indian farmers have a benefit of 4 per cent over Pakistani farmers in terms of subsidies and this can be factored into the trade policy (Chand, 2013.p24). Therefore, higher levels of subsidy in Indian agriculture compared to Pakistan should not be a major issue in terms of promoting trade between the two countries.

\section{CONCLUSION AND IMPLICATION}

Indo-Pak trade relations must be normalized if both countries maintain their bilateral talks to improve friendship and cooperation in all seriousness and in an atmosphere of peace without a shadow of terrorism. It should be the duty of both countries to come forward and create the appropriate atmosphere and with all seriousness come forward for a bilateral dialogue.

Besides, an increase in trade will be difficult without requisite financial mechanisms. Even though the central banks of India and Pakistan signed an agreement that allowed for the opening of branches by two Indian banks in Pakistan and two Pakistani banks in India in 2005, this agreement has not still been implemented. Without banking services, the provision of letters of credit and the facilitation of cross-border transactions of funds, it will be hard for firms to trade across the India-Pakistan border even when MFN is granted.

For several decades, limited people-to-people interactions because of barriers to communication have inhibited information flows that could help expand trade. Creating multilevel channels of communication is important for bringing businessmen of both the countries together-which would help bridge information gaps, reduce misconceptions and generate a significant change in the business environment of the two countries.

Finally, there is a need to engage with the media. In both India and Pakistan, the media has a powerful influence on public sentiments. Negative reporting has so far dominated India-Pakistan relationship. It would be much more helpful for reporters to create a positive environment that is conducive to holding talks on trade normalization between the two countries. The media should try to be optimistic about the benefits of trade normalization and the possible impact this could have on strengthening bilateral ties and regional integration.

The two countries must also develop the physical infrastructure required to facilitate two-way trade. The quality of road networks between India and Pakistan is low and rail networks between ports and markets are limited. It is in the interest of both countries to work together to reduce these physical bottlenecks, possibly through public-private partnerships. To develop trade in services, restrictions placed on Pakistani businessmen entering the Indian market must also be removed transfer of technology for more sustainable agricultural practices in the region.

For the agricultural sector of Pakistan to realize the potential of trade with India, it is imperative that the issue of market access be addressed in the bilateral trade negotiations between the two countries. The WTO compliant agricultural subsidies and price support given by the Indian government to its farmers are domestic issues. Given the political economy of subsidy provision in India, it is highly unlikely that India would reduce these in the near future. Therefore, in the short term, Pakistan needs to negotiate for Indian reductions in both its applied MFN tariffs on agricultural goods and the specific agriculture related NTBs that hinder Pakistan's potential exports. Opening of the Indian market to Pakistan would go a long way in pacifying the agriculture lobby. Over the medium to long run, there are considerable opportunities for cross-border investments in agriculture and processed foods, given the fact that there have been significant efforts to liberalize the investment regime in both 
countries. Likewise there is tremendous scope in trade and joint ventures/investments in inputs such as seeds and agricultural equipment. Moreover, with increased water scarcity and changing weather patterns, there is a dire need for the two countries to resolve their outstanding water issues and treat water as a common resource. Finally, both India and Pakistan should institutionalize research linkages to facilitate.

Hopefully, Golden moments in the history of India-Pakistan relationship are few and far between. The two countries should capitalize on every opportunity that comes their way. A successful meeting between the foreign secretaries could pave the way for a new era in India-Pakistan relations.

\section{NoTES}

\footnotetext{
${ }^{1}$ Surveillance of national trade policies is a fundamentally important activity running throughout the work of the WTO. At the centre of this work is the Trade Policy Review Mechanism (TPRM). All WTO members are reviewed, the frequency of each country's review varying according to its share of world trade.(www.wto.org accessed on8/9/2016)

2 The provisions of this Agreement shall not be construed to prevent:(a) Advantages accorded by any contracting party to adjacent countries in order to facilitate frontier traffic .(www.wto.org accessed on 9/9/16)

${ }^{3}$ In international economic relations and international politics, "most favoured nation" (MFN) is a status or level of treatment accorded by one state to another in international trade. The term means the country which is the recipient of this treatment must, nominally, receive equal trade advantages as the "most favoured nation" by the country granting such treatment. (Trade advantages include low tariffs or high import quotas.) In effect, a country that has been accorded MFN status may not be treated less advantageously than any other country with MFN status by the promising country.

4 NDMA is a nomenclature chosen by Pakistan to avoid political ramifications at home of giving India MFN status. India granted the MFN status to Pakistan in 1996 but Pakistan is yet to reciprocate to that. Grant of status to India would help in further boosting trade between the countries.

${ }^{5}$ Hindustan times, 20 September 2016.

${ }^{6}$ Taha M, Sayed, "Pakistan-India Trade Policy Under WTO Pakistan Horizon", Pakistan Institute of

International Affairs Vol. 57, No. 3, (July 2004), pp. 105- 119; accessed on 05/09/2016

${ }^{7}$ Verma, Manish, Verma, Rajanikant, "Bilateral Trade Between India and Pakistan- A Study of

Agriculture Sector”, Global Journal for Research analysis, vol.4 issue.12, Dec 2015 pp87-89

8 ibid

${ }^{9}$ Ahmad, Manzoor et al. (2012), Normalization of Trade with India: Opportunities and Challenges for Pakistan, Commissioned by Trade Development Authority of Pakistan (TDAP), Islamabad.
}

\section{REFERENCES}

[1] Askari, H. M. (2012, June). “New opportunities in Pakistan-India trade?", Dawn Retrieved fromhttp://www.dawn.com

[2] Bhasin, S.A. (2012). "India-Pakistan relations, 1947-2007: A documentary Study", New Delhi: Geetika Publisher.

[3] Chand, Ramesh (2006). "Free Trade Area in Asia", Academic Foundation. New Delhi.

[4] Directorate General of Commercial Intelligence and Statistics, Kolkata, India. Available on www.dgciskol.nic.in. accessed on 12/09/2016

[5] Economic Survey 2012-13, Ministry of Finance, Government of India.

[6] Economic Survey 2012-13, Ministry of Finance, Government of Pakistan.

[7] Ghuman, Ranjit. Singh,(1986). "Indo-Pak trade relation", Deep and Deep Publications, New Delhi. http://www.wilsoncenter.org/program/asia-program http://fffp.org.pk/ Accessed on 4/9/2016

[8] Indian Institute of Foreign Trade, New Delhi, India. Available on http://tedu.iift.ac.in/iift. Accessed on 09/08/2016.

[9] Khan,Ahamed.Jabed.(2012). "India-Pakistan Trade relation", IOSR Journal of Business and Management (IOSR-JBM), Vol 5, Issue 3 Nov. - Dec. 2012, PP 01-10, available on www.iosrjournals.org, Accessed on 8/9/16

[10] Kugelman, Michael \& Hathaway,M, Robert (ed).(2013). "Pakistan-India Trade: What Needs To Be Done? What Does It Matter?" wilson centre,Washington, USA, pp1 133. 
[11] Kumar, R. (2013). "India-Pakistan Trade Relations: Current and Potential”, Jinnah Institute, Pakistan.

[12] Mukherjee, A. (2009). "A brand new day or back to the future? The dynamics of India-Pakistan relations". India Review, 8(4), 404-445.

[13] Naqvi, Z. Fatima \& Schuler, Philip. (Ed). (2007, June)."The Challenges and Potential of Pakistan-India Trade". The World Bank, Washington, DC, United States of America.

[14] Noshina Saleem (2014) "Indo-Pakistan Trade Relations: A Critical Discourse: Analysis of Daily Dawn”. South Asian Studies Vol. 29, No. 1, January - July 2014, pp. 309-320

[15] Qamer, Abid, (2010). "Trade between India and Pakistan: potential items and most favored nation status", State bank of Pakistan bulletin, vol1- 45-50.Available from http://www.sbp.org.pk/research/bulletin/2005/Opinion-1.pdf.

[16] Sawhney, A. and Kumar, R. (2007). "Why SAFTA?" Paper submitted to Commonwealth Secretariat, London.

[17] Taha M, Sayed (2004 July). "Pakistan-India Trade Policy Under WTO Pakistan Horizon", Pakistan Institute of International Affairs Vol. 57, No. 3, pp. 105- 119; accessed on 05/09/2016

[18] Verma, Manish, Verma, Rajanikant,(2015). "Bilateral Trade between India and Pakistan- A Study of Agriculture Sector", Global Journal for Research analysis, vol.4 issue.12, Dec 2015 pp.87-89. 